\title{
International geological significance of the potential Al-Medina volcanic UNESCO Global Geopark Project in Saudi Arabia revealed from multi-satellite remote sensing data
}

\author{
Han $\mathrm{Fu}^{1,2,3}$, Bihong $\mathrm{Fu}^{1^{*}}$ (D), Pilong Shi ${ }^{1}$ and Yuanyuan Zheng ${ }^{4}$
}

\begin{abstract}
UNESCO Global Geoparks should be of international geological significance in terms of their scientific quality, rarity, aesthetic appeal and tourism value. At least nine Cenozoic volcanic fields are developed in the western Saudi Arabia, with a total area of $180,000 \mathrm{~km}^{2}$. In this paper, the geological and geomorphological features of these volcanic fields induced by the expansion of the Red Sea are interpreted and displayed using multi-source satellite images, such as Landsat-8 OLI (Operational Land Imager) and Gaofen-2 data. Our results show that the Al-Medina volcanic field (AMVF) has great prospects as the aspiring volcanic Geopark in Saudi Arabia. This study indicates that: (1) AMVF has international geoscientific significance and rare natural attribute because the volcanic fields are induced by the rising mantle plume and rare examples of white volcanoes comprised mainly from felsic rock; (2) AMVF has abundant volcanic landscapes, including completely preserved cones and craters and multi-phase lava flows from different eruption stages, which have great aesthetic appreciation and tourism values to attract the general public; (3) AMVF is close to the second holy city of Islam-Medina, which has convenient transportation and is suitable to develop tourism to promote the development of the local economy; (4) AMVF had erupted repeatedly (the latest eruption was in 1256 AD), establishment of the UNESCO Global Geopark Project can not only prevent potential geological hazard risks to the people living in Medina city from future volcanic eruption events, but also provide better protection and conservation to geoheritage sites being damaged by human activities, for example setting protected boundaries of AMVF to avoid the destruction of volcanic landscape integrity caused by urban expansion.
\end{abstract}

Keywords: Geoheritage, Al-Medina volcanic field, Late Quaternary, Scientific value and aesthetic appeal, Multi-source remote sensing data

\section{Introduction}

Geological heritage or Geoheritage includes "pure" geological and geomorphological heritage, representing the entity of unique features of the Earth's crust that can be employed for the purposes of science, education and tourism [1]. Geoheritage has different types

\footnotetext{
*Correspondence: fubh@aircas.ac.cn

${ }^{1}$ Key Laboratory of Digital Earth Science, Aerospace Information Research

Institute, Chinese Academy of Sciences, Beijing 100094, China

Full list of author information is available at the end of the article
}

(geomorphological, sedimentary, igneous, etc.) and forms (natural outcrops and landscapes, etc.), which is the subject of geoconservation.

Two main types of localities exhibiting geoheritage that are officially designated are geosites and geoparks. The former are relatively small objects or areas representing unique phenomena. Geoparks are areas specially designated for geoheritage exploitation for the purposes of tourism, education and science, as well as for their conservation [1]. Additionally, geoparks bring jobs to rural and indigenous people, in turn helping to protect sites of
Springer Open

(c) The Author(s) 2021. Open Access This article is licensed under a Creative Commons Attribution 4.0 International License, which permits use, sharing, adaptation, distribution and reproduction in any medium or format, as long as you give appropriate credit to the original author(s) and the source, provide a link to the Creative Commons licence, and indicate if changes were made. The images or other third party material in this article are included in the article's Creative Commons licence, unless indicated otherwise in a credit line to the material. If material is not included in the article's Creative Commons licence and your intended use is not permitted by statutory regulation or exceeds the permitted use, you will need to obtain permission directly from the copyright holder. To view a copy of this licence, visit http://creativecommons.org/licenses/by/4.0/. The Creative Commons Public Domain Dedication waiver (http://creativecommons.org/publicdomain/zero/1.0/) applies to the data made available in this article, unless otherwise stated in a credit line to the data. 
importance and promote geoheritage. UNESCO (United Nations Educational, Scientific and Cultural Organization) Global Geoparks are single, unified geographical areas where sites and landscapes of international geological significance are managed with a holistic concept of protection, education, and sustainable development. Their bottom-up approach of combining conservation with sustainable development while involving local communities is becoming increasingly popular. At present, there are 169 UNESCO Global Geoparks in 44 countries [2]. The distribution of UNESCO Global Geoparks around the world is presented in Fig. 1. It shows that current UNESCO Global Geoparks are mainly distributed in southwestern Europe and eastern Asia. Among them, the volcanic Global Geoparks are mainly distributed in China, Japan, Korea, Peru, and Turkey [2].

One of the geoheritage features, the volcanic fields, which are widespread on Earth, such as scoria cones, tuff rings, maars, lava flows and lava lakes, help to increase in interest and wealth of new science knowledge [4]. The establishment of volcanic geoparks and geoheritage sites is becoming increasingly popular worldwide. UNESCO Global Geoparks and the European Geopark Network have numerous geoparks which achieved their status due to their volcanic geoheritage [4].

The Saudi Arabia, with an area of 2,250,000 km², is ranking the 14th in the world. Induced by the expansion of the Red Sea, Saudi Arabia has developed at least nine Cenozoic basaltic volcanic fields in the western part, with a total area of $180,000 \mathrm{~km}^{2}$ [4]. However, there is still no geoheritage site in Saudi Arabia that has been inscribed on the UNESCO Global Geoparks.

The Al-Medina volcanic field (AMVF), part of the Harrat Rahat in northwest of the Saudi Arabia, is the worth notable active volcanic field characterized by the occurrence of two historical eruptions approximately in 641 and $1256 \mathrm{AD}$. The evolution, lithology, geochronology, geochemistry and the hazard analysis on the region [5-9] have provided important information to the inventory of the volcanic heritage. Here, we identify significant volcanic features in AMVF by using multi-source satellite images, including Moderate-resolution Imaging Spectrometer (MODIS), Landsat-8 OLI (Operational Land Imager) and China Gaofen-2 (GF-2) data. The results of our studies indicates that the AMVF could be organized and promoted as the UNESCO Global Geopark in the Kingdom of Saudi Arabia.

Remote sensing data products (aerial photographs and satellite images) give direct information on the landscape-the surface features of the Earth, and therefore geomorphological investigations are most easy to carry out based on such data. Through different bands combinations, different lithology and eruption periods of lavas can be highlighted. Remote sensing investigations have a two-fold purpose: (a) to view the ground features in a different perspective, on a different scale, or in a different spectral region, and (b) to reduce the amount of field work involved in covering the entire study area, especially when the target in the region are far away and difficult and expensive to access.

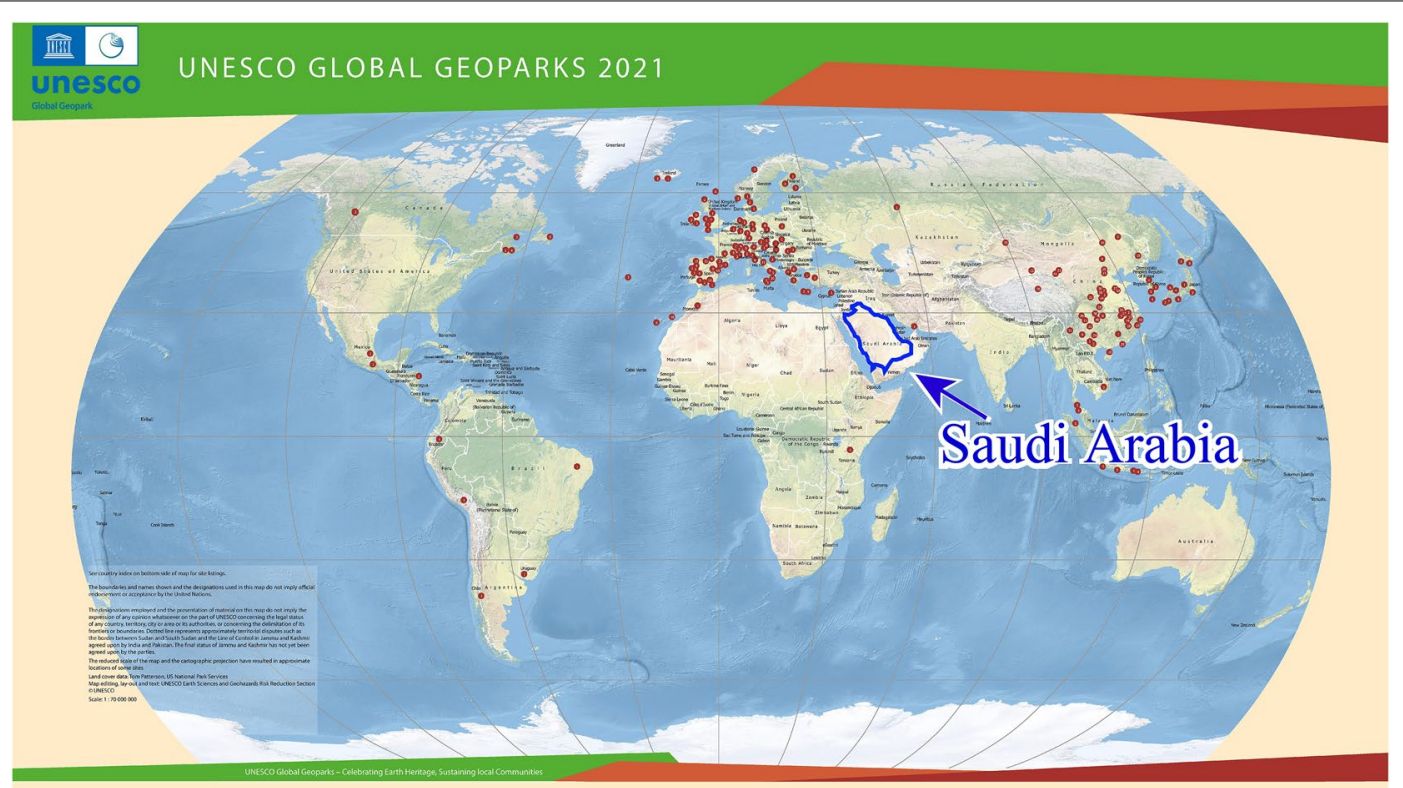

Fig. 1 The distribution of UNESCO designated Global Geoparks around the world [3] 
Our approach focus on using remote sensing techniques, supplemented by a literature review and field studies. The approach applied in this study was as follows. Following the introduction, a detailed description of the study area in Saudi Arabia is presented in Sect. 2. In Sect. 3, the methodology to interpret the geological and geomorphological features of AMVF by using multisource satellite images and the results are described in Sect. 4. In Sect. 5, we discuss AMVF fits the criteria for consideration as a potential volcanic Geopark Project. The conclusions are drawn in the last section.

\section{Geological background}

Kingdom of Saudi Arabia, referred to as Saudi Arabia, is located in the Arabian Peninsula in the western Asia. It borders the Persian Gulf in the east and the Red Sea in the west, with a $2,437 \mathrm{~km}$-long coastline, as shown in Fig. 2.

Saudi Arabia occupies most of the Arabian Peninsula topographically higher in the west and lower in the east. Along the Red Sea, there is a "backbone" of the Arabian Peninsula, named "Tuwaiq Mountain chain", extending in a north-south direction in general. In the east of the mountains, the terrain gradually declines towards the eastern plain, where a large portion is covered by sand dunes and rocky regolith [12].

The Red Sea Rift 2000 km-long striking NNW-SSE, forms a broad zone of active deformation between Africa and Arabia [6]. Rifting of the Red Sea began about $30 \mathrm{Ma}$ ago, separating the western edge of the Arabian Plate from African Plate [13], as shown in Fig. 2. Following that, the late Cenozoic geodynamic

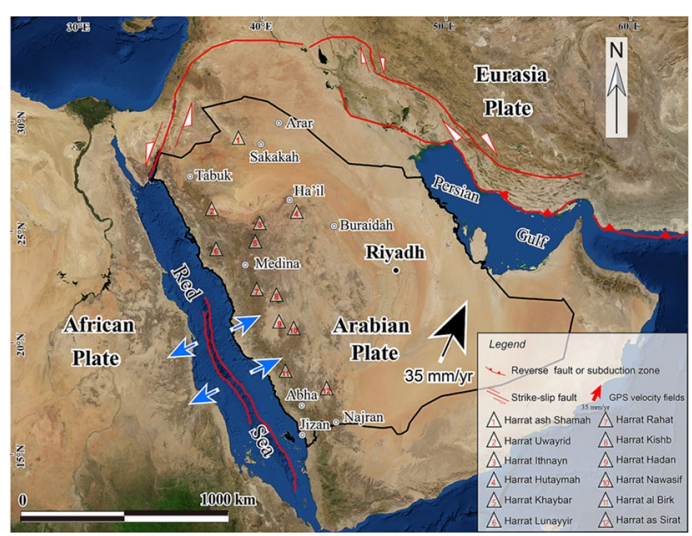

Fig. 2 A MODIS remote sensing image shows the distribution of Cenozoic volcanic fields in Saudi Arabia. Note that the schematic Cenozoic tectonic map of the Arabian and African plates also displayed that the northward subduction of Arabian plate toward the Eurasia plate has led to the extension of the Rea Sea (modified after $[10,11])$ evolution of the Arabian Shield area was mainly controlled by (1) extensional processes as a consequence of the complex kinematic interactions that developed the Red Sea Basin [14-17], which are moving the Arabian Plate towards NE with a speed of 1.6-2 cm/yr. [18-20]; (2) continental collision between Arabia and Eurasia to the east since the middle Miocene [21-24].

In response to this complex tectonics of the Arabian Plate, a series of large Cenozoic volcanic fields and volcanic rocks mainly developed along its western margin by the rising mantle plume induced by expansion of the Red Sea after the continental plate collision between Arabian and Eurasian plates [5, 7, 26-31], as shown in Fig. 3. At least nine intracontinental Cenozoic basaltic lava fields parallel to the Red Sea Rift are developed in western Arabian Shield (Fig. 2), with a total area of $180,000 \mathrm{~km}^{2}$. These volcanoes and lava fields form a $600 \mathrm{~km}$-long unique volcano chain from north to south in western Arabian Shield, named "Mecca-MedinaNafud Volcano Line (MMN Line)". Among the volcanoes, the Al-Medina volcanic field (AMVF), part of the Harrat Rahat in northwest of the Arabian Plate, is the worth notable active volcanic field characterized by two historical eruptions approximately in 641 and $1256 \mathrm{AD}$ [6]. AMVF is characterized by a central NNW-SSE volcanic chain that extends about $100 \mathrm{~km}$ to Medina city in the north. This volcanic chain consists of more than 500 scoria cones (up to $30-200 \mathrm{~m}$ high) surrounded by fields of coalescing low viscosity basaltic lava flows [6].

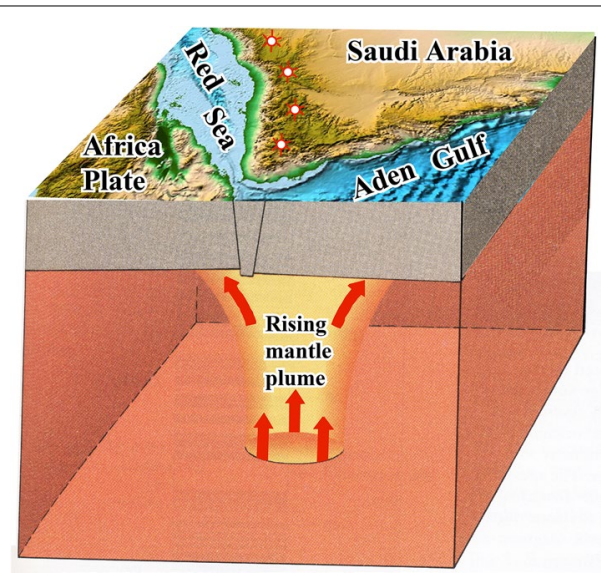

Fig. 3 The three-dimensional (3D) geodynamic concept diagram showing that the Cenozoic volcanoes in western Saudi Arabia are formed by the rising mantle plume induced by expansion of the Red Sea after the plate collision between Arabian and Eurasian plates (The figure is modified according to [25], the red stars mark the active volcanoes) 


\section{Methodology}

Based on the geological background, the geological and geomorphological features of the AMVF in western Saudi Arabia are interpreted using Landsat-8 OLI and Gaofen-2 data, respectively.

\section{Remote sensing data Landsat- 8 satellite}

Landsat satellites came from the National Aeronautics and Space Administration (NASA). Landsat-8 satellite was successfully launched on February 11, 2013, carrying two sensors: OLI and TIRS (Thermal Infrared Sensor). The technical specifications of the Landsat- 8 data are listed in Table 1.

The Landsat- 8 image used in this study is the Level $1 \mathrm{~T}$ data product with spatial resolution of $30 \mathrm{~m}$, which has undergone systematic radiometric calibration and geometric correction by the United States Geological Survey (USGS) (https://www.usgs.gov/). The investigated Landsat-8 image was acquired on September 24, 2018.

\section{Gaofen-2 (GF-2) satellite}

GF-2 satellite is the first civilian optical remote sensing satellite with spatial resolution up to $1 \mathrm{~m}$ developed by China. It was launched on August 19, 2014, carrying two cameras: $1 \mathrm{~m}$ panchromatic and $4 \mathrm{~m}$ multispectral cameras. The technical specifications of the GF-2 are listed in Table 2.

In this paper, we collected two Level 1-A GF-2 remote sensing images over the AMVF area which were acquired on February 10, 2018.

\section{Interpretation of the Landsat-8 data over the AMVF}

The spectral reflection characteristics of volcanic lavas (including pyroclasts, such as ash, lapilli, and scoria)

Table 1 The main technical specifications of the Landsat-8 data

\begin{tabular}{llcc}
\hline No. & Band & Wavelength $(\boldsymbol{\mu m})$ & $\begin{array}{l}\text { Spatial } \\
\text { resolution } \\
(\mathbf{m})\end{array}$ \\
\hline 1 & Coastal & 30 \\
2 & Blue & $0.43-0.45$ & 30 \\
3 & Green & $0.45-0.51$ & 30 \\
4 & Red & $0.53-0.59$ & 30 \\
5 & NIR (near-infrared) & $0.64-0.67$ & 30 \\
6 & SWIR1 (short wave infrared) & $1.57-1.65$ & 30 \\
7 & SWIR2 & $2.11-2.29$ & 30 \\
8 & PAN & $0.50-0.68$ & 15 \\
9 & Cirrus & $1.36-1.38$ & 30 \\
10 & TIR1 (thermal infrared) & $10.60-11.19$ & 100 \\
11 & TIR2 & $11.50-12.51$ & 100 \\
\hline
\end{tabular}

Table 2 The main technical specifications of GF-2 data

\begin{tabular}{llll}
\hline No. & Band & Wave length $(\boldsymbol{\mu m})$ & $\begin{array}{l}\text { Spatial } \\
\text { resolution } \\
(\mathbf{m})\end{array}$ \\
\hline 1 & Pan & $0.45-0.90$ & 1 \\
2 & Blue & $0.45-0.52$ & 4 \\
3 & Green & $0.52-0.59$ & 4 \\
4 & Red & $0.63-0.69$ & 4 \\
5 & NIR (near infrared) & $0.77-0.89$ & 4 \\
\hline
\end{tabular}

with different lithological components or eruption periods are different in the remote sensing image. According to [32], the spectral reflectance of different weathering degrees in basalt volcanic lavas has a noticeable distinction in thermal infrared bands [32]. Therefore, Band 10 or Band 11 of Landsat- 8 can be used to distinguish the weathering degree of volcanic lava. In addition, considering that the volcanic lava after weathering may contain hematite and aluminum elements, the near-infrared band (Band 5) and shortwave infrared band (Band 6 or Band 7) are selected to identify hematite and aluminum in the weathered lavas. Finally, Band 11, Band 5 and Band 7 are arranged for Red, Green and Blue channels of the Landsat- 8 remote sensing image, respectively, which is shown in Fig. 4.

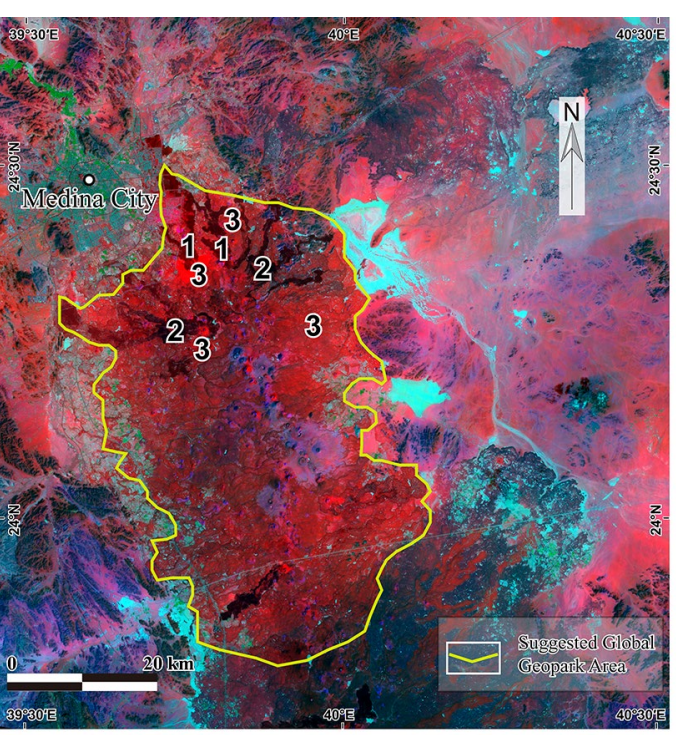

Fig. 4 The pseudo-color composite of the Landsat-8 image reveals the volcanic lavas from different eruption periods appearing different colors of the AMVF (RGB as 11,5,7); Note 1, 2, and 3 represent the volcanic lavas of the latest eruption period, the younger eruption period and the oldest eruption period, respectively 


\section{Interpretation of the GF-2 data of over the AMVF}

In order to judge the eruption periods of the Medina volcanic lavas more clearly, we obtained the GF-2 data of the same area (Fig. 5).

The pseudo-color synthesis of the GF-2 data shows that volcanic landforms are widely distributed with different colors in the AMVF, and it is speculated that at least four eruption periods can be identified: (1) the purple part (numbered 1 in Fig. 5); (2) the dark green part (2 in Fig. 5); (3) the lighter green part (3 in Fig. 5) and (4) the off-white part (4 in Fig. 5). There are about 50 volcano craters with different landforms in the AMVF, and most of them are cinder cones, while some are shield-shaped volcanoes.

Geological interpretation and analyses of the GF-2 and Landsat- 8 images of the AMVF generated a 1:50,000 volcanic geological interpretation map (Fig. 6), combining the results of previous research $[5,6,8]$, suggest that there are at least four eruption periods as following.

1) The red pattern (numbered 1) in Fig. 6, corresponding to the purple part ( 1 in Fig. 5), belongs to the Qm7: 1500 BP-1256 AD, which is the latest volcanic lavas. According to the existing geological data, the last eruption of this volcano occurred in AD 1256. The latest lava flows is quite close to Medina City;

2) The orange pattern (numbered 2) in Fig. 6, corresponding to the dark green part (2 in Fig. 5), belongs

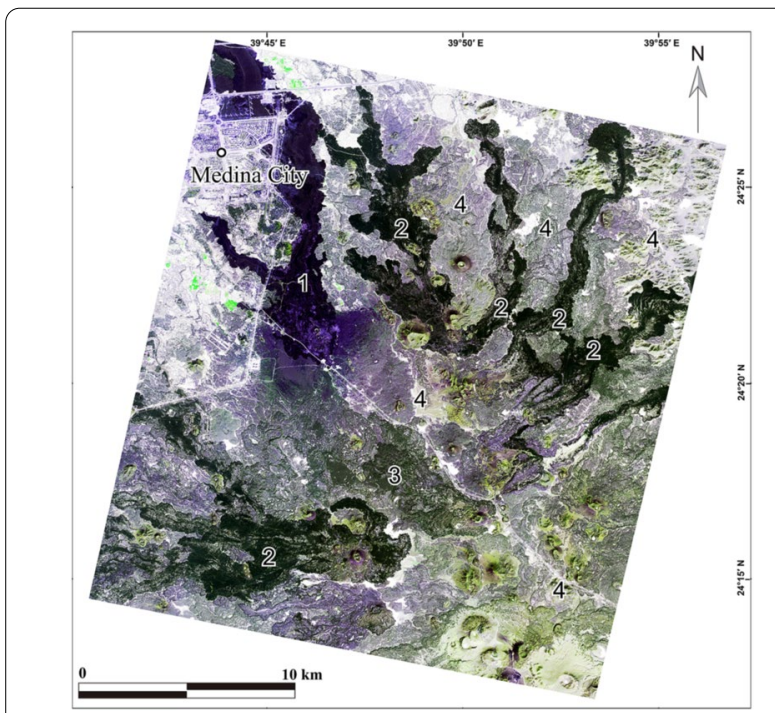

Fig. 5 GF-2 satellite remote sensing image reveals the volcanic lavas from 4 different eruption periods of the AMVF (RGB as 3,4,1); Note 1 , 2,3 , and 4 represent the volcanic lavas of the latest eruption period, the younger eruption period, the older eruption period and the oldest eruption period, respectively

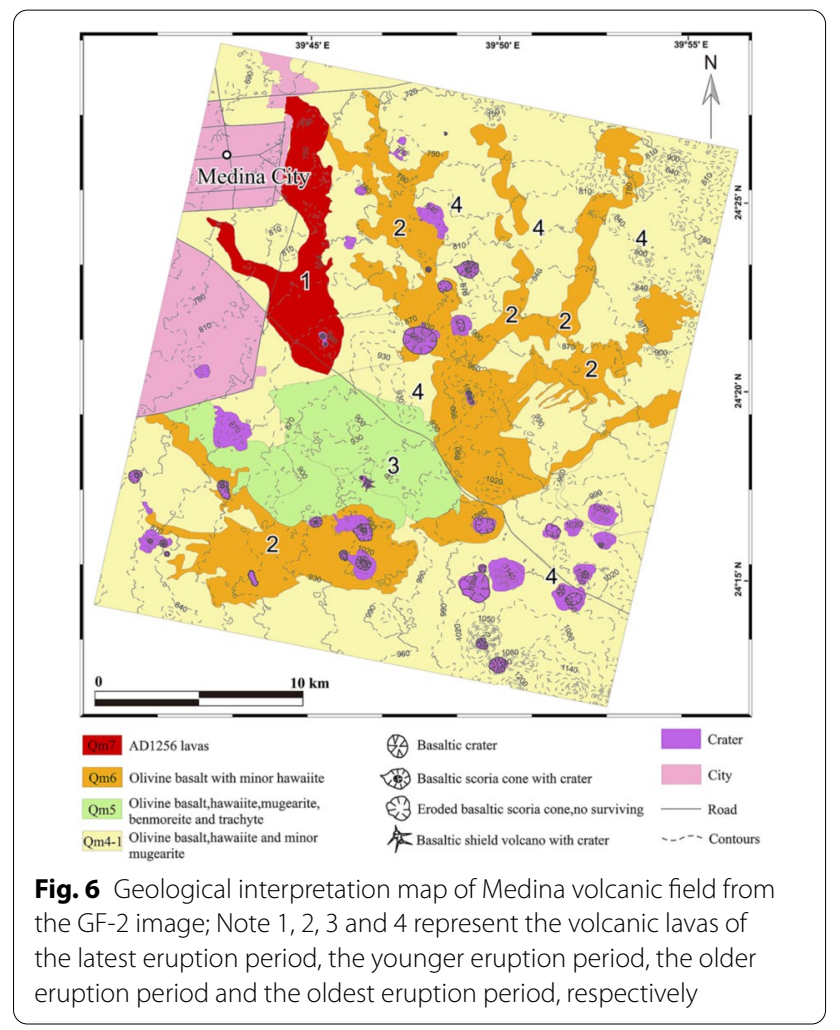

to the Qm6: 4500-1500 BP, which represents the younger volcanic lavas;

3) The bright green pattern (numbered 3) in Fig. 6, corresponding to the lighter green part (3 in Fig. 5), belongs to the Qm5: 0.3 Ma-4500 BP, which represents the older volcanic lavas;

4) The bright yellow pattern (numbered 4) in Fig. 6, corresponding to the off-white part (4 in Fig. 5), belongs to the Qm1-4: 1.7 Ma-0.3 Ma, which represents the oldest volcanic lavas.

\section{Three-dimensional (3D) perspective view images of the AMVF}

Two typical regions in north and south of the AMVF were selected to generate 3D perspective view images, as shown in Figs. 7, 8 and 9. These images were obtained by superimposing the GF-2 remote sensing image on the digital elevation model (DEM) data with stretching the elevation value at the same time. The Advanced Spaceborne Thermal Emission and Reflection Radiometer Global Digital Elevation Model (ASTER GDEM) data with a spatial resolution of $30 \mathrm{~m}$ were used here.

Two different volcanic lavas erupted in the north of the AMVF. The purple pattern is the latest volcano lavas from $1256 \mathrm{AD}$ around Medina city. Partial of the city was built in this period of lava flows, for example the roads 


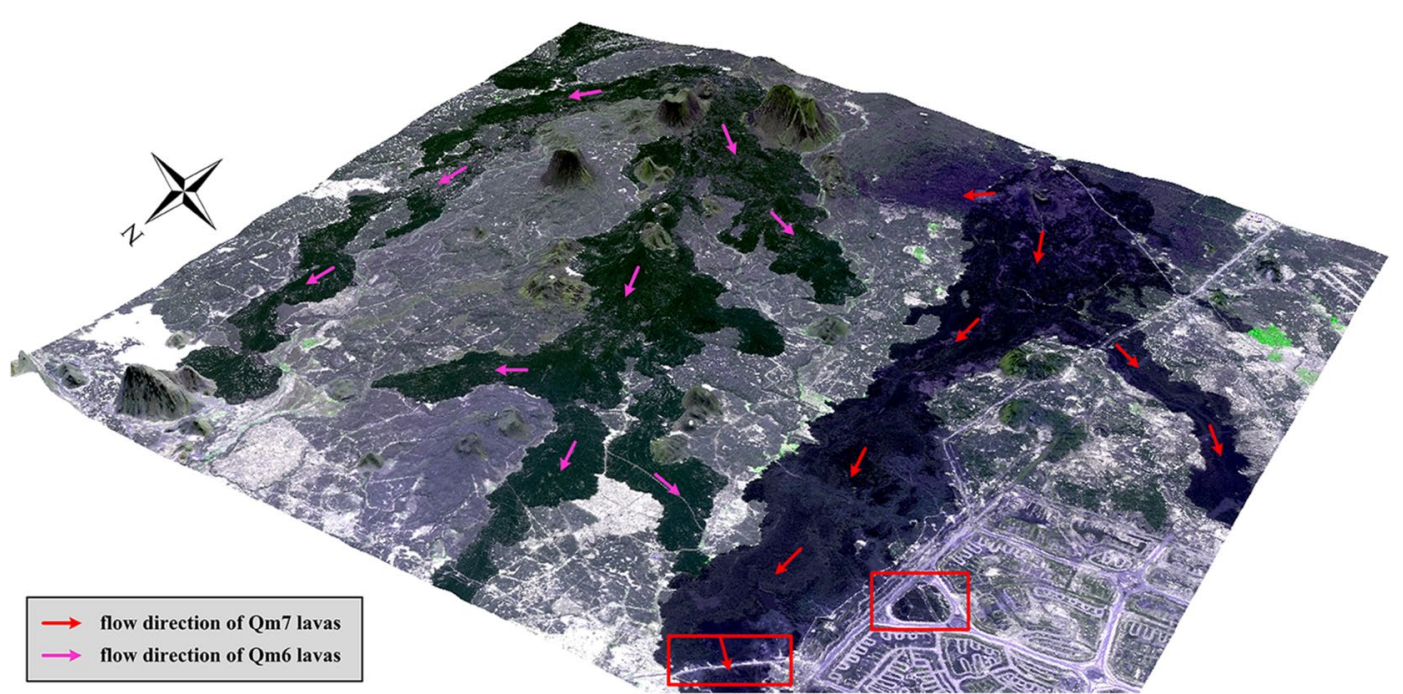

Fig. 7 3D perspective view image reveals the different eruption periods and the flows direction in the northwestern part of the AMVF (view: WN-ES)

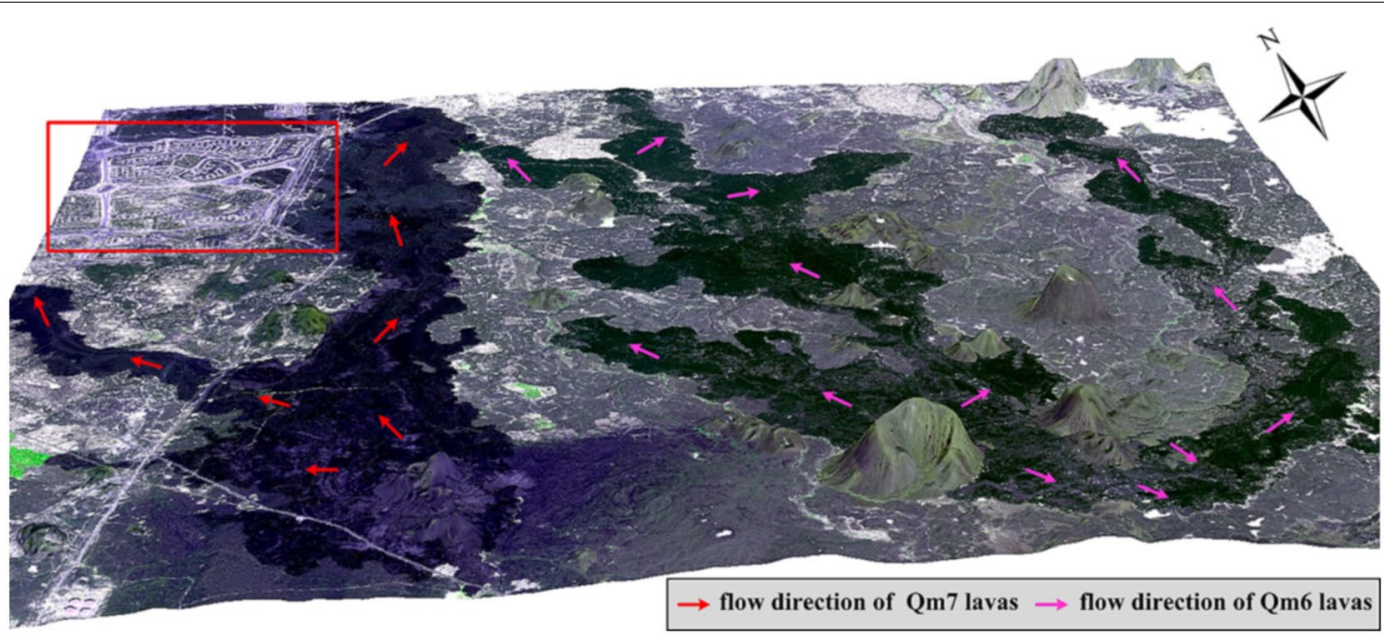

Fig. 8 3D perspective view image reveals the different eruption periods and the flows direction in the northwestern part of the AMVF (view: N-S)

are through these lava flows (as the red rectangles indicated in Figs. 7 and 8), indicating that human activities like urban expansion have caused damage and destruction to this volcanic geological site.

From the 3D perspective view image (Fig. 9), it can be observed that the multiple volcanic cones and multistage volcano lavas developed in the southern part of the AMVF. These different shaped volcanos are wellpreserved. Moreover, because of the sparse vegetation, the coverage relationship among the volcano lavas generated in different eruption periods can be identified clearly, which is benefitting for future tourism viewing. Rare examples of white volcanoes comprised mainly of the felsic rock commodity [9] can be seen clearly in some craters as shown in Fig. 9, which is a unique volcanic type among in the world.

\section{Results}

The pseudo-color synthesis of the Landsat- 8 data shows that the volcanic lavas of AMVF can be divided into at least three periods: (1) the dark red part (marked by 1 in Fig. 4); (2) the black part (2 in Fig. 4) and (3) the lighter red part ( 3 in Fig. 4).

The geological interpretation map from the GF-2 image reveals that the AMVF had experienced multiple eruptions, and the exposed volcanic lavas appear in different 


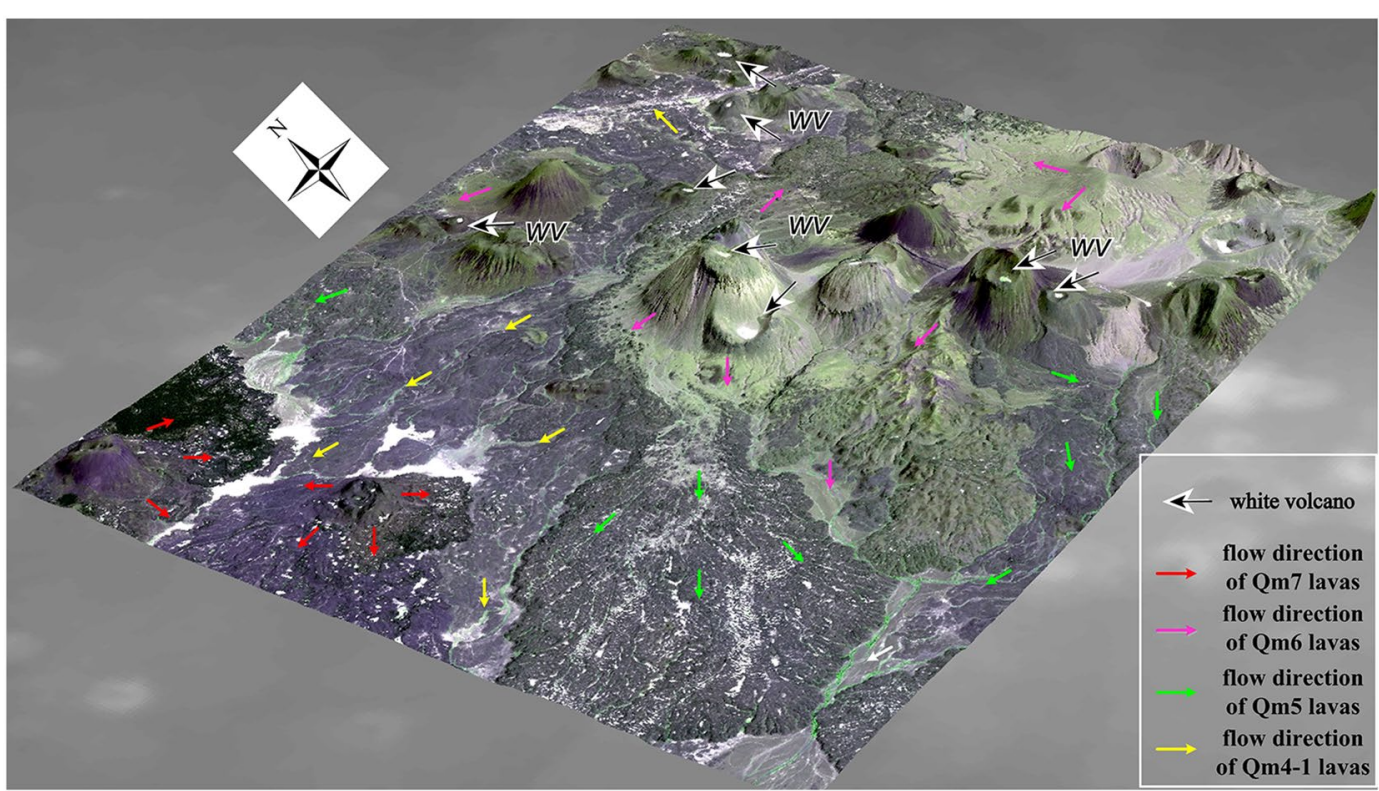

Fig. 9 3D perspective view image reveals the lava flows generated in different eruption periods and the flows direction in the southern part of AMVF (view: WS-EN); WV means white volcano

colors and forms after a long time of weathering. The lava flows produced from the latest eruption (Qm7) in the lava area are very close to Medina city, indicating that future volcanic eruption may have potential disaster risks to the city. In addition, partial Medina city located in this lava flows, also indicates that human activities like urban expansion had caused damage and destruction to this volcanic geological site. Therefore, the AMVF deserves more appropriate protection and management.

\section{Discussion}

The interpretation results of multi-source satellite images indicate that the AMVF in western Saudi Arabia has the potential and advantage to become a volcanic geopark for its uniqueness compared with other existing volcanic geoparks:

1) Tectonically, the Medina volcanic field is related to the hot rising mantle plume induced by the expansion of the Red Sea after the plate collision between Arabian and Eurasian Plates since the middle Miocene (Figs. 2, 3). Its geodynamic mechanism is entirely different from the back-arc volcanoes, such as the Japanese islands, and the intracontinental volcanoes, such as the Wudalianchi volcanoes in China [32]. The former is induced by the collision between oceanic and continental plates [25, 33], while the Wudalianchi volcanoes are formed by the deep subduction and dehydration of the west Pacific stagnant slab, possibly through hot and wet upwelling in the big mantle wedge under the NE China [32, 34-37].

2) Concerning the volcanic landscape, the AMVF has developed abundant multi-phase volcano lava flows, including lave tubes, ropy pahoehoe lavas and aatype lavas [38], as well as wholly preserved scoria cones and craters (as shown in Fig. 10a-d, respectively). Compared with the existing UNESCO's volcanic geoparks, such as Wudalianchi UNESCO Global Geopark [32] and Leiqiong UNESCO Global Geopark [39], the AMVF has not only kinds of wellconserved volcanic geological sites, but also striking volcanic landforms. Due to the sparse cover of vegetation, the lava flows from different eruption stages are well exposed on the surface, appearing in different colors and landforms. Moreover, the coverage relationship among the multi-stage volcanic lavas produced in different eruption periods is apparent, which makes AMVF a natural geological museum showing abundant volcanic landforms and aesthetic charm to the general public.

3) About the lithologic characteristics, there are rare and distinctive white volcanoes comprised mainly of the felsic rock commodity in AMVF, which is a unique volcanic type among the world and totally different from the existing volcanic geoparks. So it has international geological significance and unique scientific, aesthetic and tourism value. 

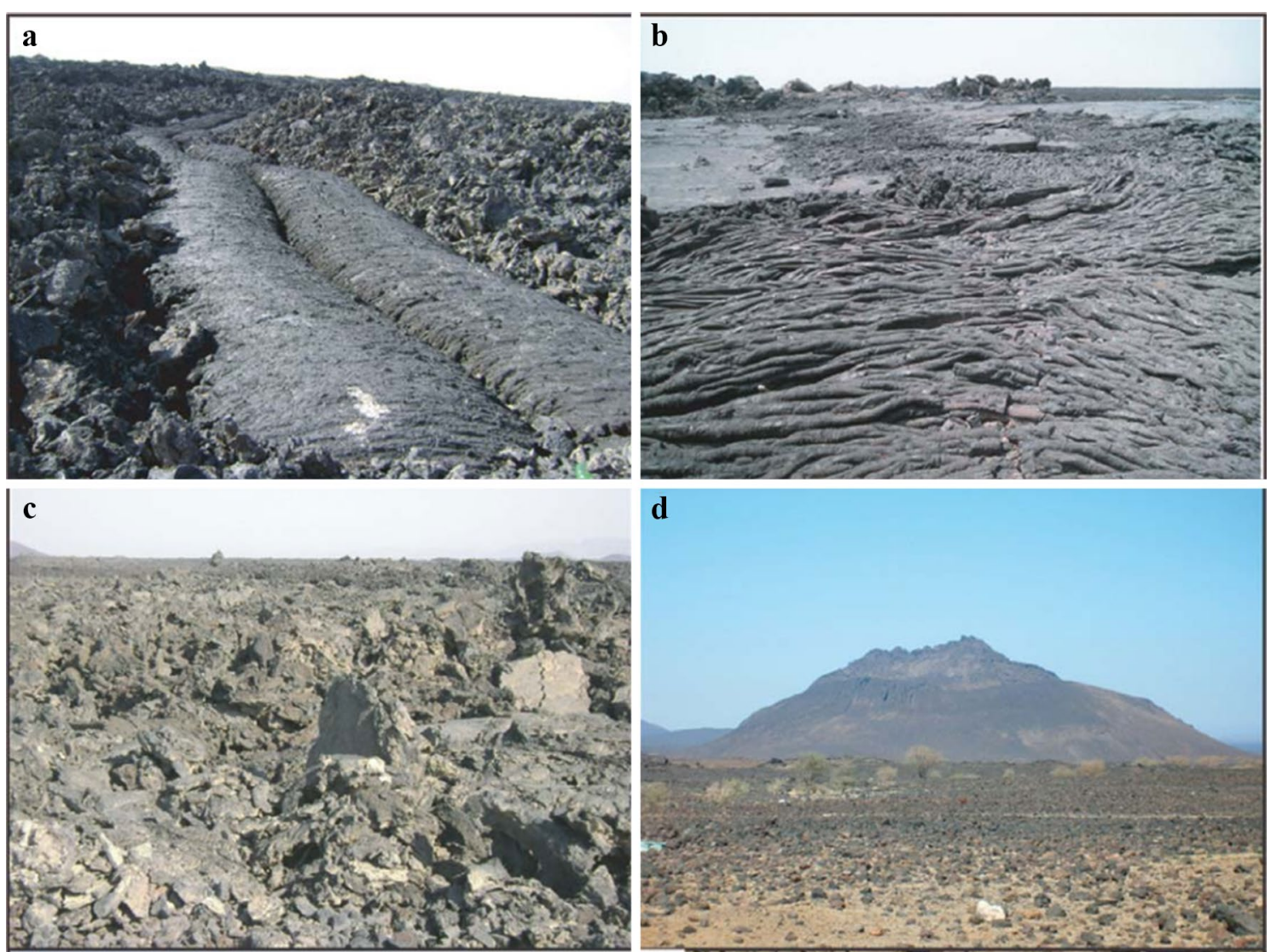

Fig. 10 Field photographs showing some volcanic landscapes of the AMVF: a lava tubes recorded within the eastern parts of Qm7; $\mathbf{b}$ ropy pahoehoe lava flows near the vent zone of the 1256 AD historic eruption; c aa-type lava flows of the 1256 AD historic eruption; $\mathbf{d}$ trachytic cone of Qm4. (The picture is from [6])

4) Concerning the volcanic hazard, AMVF is very close to the Medina city, the second holy city of Islam, which has convenient transportation and is suitable for the general public to visit and developing tourism, such as hiking trails, geotourism and volcano tourism, which is one of the sustainable human activities that the Global Geoparks Network is promoting. Moreover, the latest eruption of AMVF occurred in 1256 AD, ca. 765 years ago. Therefore, future possible volcano eruptions will have potential disaster risks to the urban development. Establishment of the UNESCO Global Geopark Project, for example setting protected boundaries (as suggested in Fig. 4), can not only prevent potential geological hazard risks to the people in Medina city from future volcanic eruptions, but also provide better protection and conservation to geoheritage sites from being damaged by urban expansion.
The comparative analysis of geological features between AMVF and other existing volcanic Global Geoparks are shown in Table 3.

To achieve a sustainable management and protection of AMVF, the local government and residents should exchange their opinions and experiences to create a protection regulation for this geoheritage. And then they are suggested to work together to have a comprehensive conservation status (such as establishment of National Park, Natural Park, Natural Monument or scenic area) and develop some tourism activities (such as hiking trails, geotourism, and volcano tourism) for the AMVF before the recognition by UNESCO as a Global Geopark.

\section{Conclusions}

The interpretations and analyses of geological and geomorphical features of volcanic fields based on multisource remote sensing data can effectively identify the 
Table 3 The comparative analysis of geological features between AMVF and other existing volcanic Global Geoparks

\begin{tabular}{|c|c|c|c|}
\hline Volcanic geoparks & Tectonics & Landscape & Lithological characteristics \\
\hline AMVF & $\begin{array}{l}\text { The extension of the Rea Sea caused by the } \\
\text { continental collision between the Arabian } \\
\text { and Eurasian plates }\end{array}$ & $\begin{array}{l}\text { Multi-stages lava flows with sparse vegeta- } \\
\text { tion }\end{array}$ & Basalt with rare white volcanos \\
\hline Unzen volcanic area UGGP & $\begin{array}{l}\text { The collision between oceanic and conti- } \\
\text { nental plates }\end{array}$ & Lava flows with sparse vegetation & Basalt \\
\hline Wudalianchi UGGP & $\begin{array}{l}\text { The deep subduction and dehydration of } \\
\text { the west Pacific stagnant slab }\end{array}$ & Multi-stages lava flows with vegetation & Basalt \\
\hline Leiqiong UGGP & $\begin{array}{l}\text { The deep subduction and dehydration of } \\
\text { the west Pacific stagnant slab }\end{array}$ & Multi-stages lava flows with vegetation & Basalt \\
\hline
\end{tabular}

scientific, aesthetic and tourism values of the potential volcanic Geopark. Furthermore, help to recognize the suitable location and boundary of the potential UNESCO Global Geopark Project. The results indicate that the AMVF in western Saudi Arabia has the potential and advantage to become a volcanic Geopark due to its unique international geo-scientific significance and rare natural value in geodynamic mechanism, volcanic landscape and lithological characteristics. Furthermore, the AMVF has great aesthetic appreciation to attract the general public and is suitable for developing tourism to promote the economic and social development. It is suggested that the Saudi Arabia government should formulate management measures to guarantee the geoheritage sites and landscapes will be managed with a holistic concept of conservation and sustainable development before declaring the AMVF as UNESCO Global Geopark Project.

\section{Abbreviations}

UNESCO: United Nations Educational, Scientific and Cultural Organization; MODIS: Moderate-resolution imaging spectroradiometer; OLI: Operational Land Imager; AMVF: Al-Medina volcanic field; MMN Line: Mecca-MedinaNafud Volcano Line; NASA: National Aeronautics and Space Administration; TIRS: Thermal infrared sensor; NIR: Near infrared; SWIR: Short wave infrared; TIR: Thermal infrared; DEM: Digital elevation model; ASTER GDEM: Advanced Spaceborne Thermal Emission and Reflection Radiometer Global Digital Elevation Model.
\end{abstract}

\section{Acknowledgements}

We appreciate editors and anonymous reviewers for their constructive suggestions and comments that help us significantly improve this paper's quality. Thanks Xiaochuan Qin, Jingxia Li and Jiaxin Du from the HIST natural heritage research group for their help to this study.

\section{Authors' contributions}

Conceptualization, B.F. and H.F.; methodology, H.F. and B.F.; formal analysis, H.F., P.S. and Y.Z.; resources, B.F.; data curation, H.F. and P.S.; writing-original draft preparation, H.F.; writing-review and editing, H.F. and B.F.; figures, H.F. and P.S.; visualization, H.F.; supervision, B.F.; funding acquisition, B.F. All authors read and approved the final manuscript.

\section{Funding}

This research was supported by the Strategic Priority Research Program of Chinese Academy of Sciences (XDA051002) and the Second Tibetan Plateau Scientific Expedition and Research Program (STEP) (2019QZKK0901).

\section{Availability of data and materials}

The Landsat- 8 remote sensing data used in this study are available in the https://www.usgs.gov/.

\section{Declarations}

\section{Competing interests}

The authors declare no conflict of interest.

\section{Author details}

${ }^{1}$ Key Laboratory of Digital Earth Science, Aerospace Information Research Institute, Chinese Academy of Sciences, Beijing 100094, China. ${ }^{2}$ University of Chinese Academy of Sciences, Beijing 100049, China. ${ }^{3}$ State Key Laboratory of Space-Ground Integrated Information Technology, Beijing Institute of Satellite Information Engineering, Beijing 100029, China. ${ }^{4}$ Chinese Academy of Geological Sciences, Beijing 100037, China.

Received: 30 April 2021 Accepted: 7 October 2021

Published online: 10 November 2021

\section{References}

1. Sallam ES, Ruban DA, Mostafa MT, Elkhodery MK, Alwilily RL, Molchanova TK, Zorina SO. Unique desert caves as a valuable geological resource: first detailed geological heritage assessment of the Sannur Cave, Egypt. Arab J Geosci. 2020;13:141. https://doi.org/10.1007/s12517-020-5176-4.

2. UNESCO Global Geopark. http://www.unesco.org/new/en/natural-scien ces/environment/earth-sciences/unesco-global-geoparks/.

3. UNESCO Global Geopark map in 2021. https://en.unesco.org/sites/defau It/files/poster_map_geopark_2021_compressed_0.pdf.

4. Moufti MR, Nemeth K. The Intra-Continental Al Madinah Volcanic Field, Western Saudi Arabia: a proposal to establish Harrat Al Madinah as the first volcanic geopark in the Kingdom of Saudi Arabia. Geoheritage. 2013;5(3):185-206.

5. Camp VE, Roobol MJ. The Arabian continental alkali basalt province. Part 1. Evolution of Harrat Rahat, Rahat, Kingdom of Saudi Arabia. Geol Soc Am Bull. 1989;101(1):71-95.

6. Moufti MR, Moghazi AM, Ali KA. 40Ar/39Ar geochronology of the Neogene-Quaternary Harrat Al-Madinah intercontinental volcanic field, Saudi Arabia: implications for duration and migration of volcanic activity. J Asian Earth Sci. 2013;62(Jan30):253-68.

7. Moufti MR, Moghazi AM, Ali KA. Geochemistry and Sr-Nd-Pb isotopic composition of the Harrat Al-Madinah Volcanic Field, Saudi Arabia. Gondwana Res. 2012;21(2-3):670-89.

8. El Difrawy MA, Runge MG, Moufti MR, Cronin SJ, Bebbington M. A first hazard analysis of the Quaternary Harrat Al-Madinah volcanic field, Saudi Arabia. J Volcanol Geother Res. 2013;267:39-46.

9. Michael AK, Abdulaziz AS, Khalid AR. The White Volcanoes of Harrat Khaybar, north of Al-Madinah. Geotourism. 2014;2(37):3-12.

10. Jackson JA, Haines AJ, Holt WE. The accommodation of Arabia-Eurasia plate convergence in Iran. J Geophys Res. 1995;100:15205-19. 
11. Fu BH, Ninomiya $Y$, Lei $X L$, Toda S, Awata Y. Mapping active fault associated with the 2003 Mw 6.6 Bam (SE Iran) earthquake with ASTER 3D images. Rem Sens Environ. 2004;92(2):153-7.

12. Abdulla Homoud Tariki BS. Geology of Saudi Arabia. A thesis for the Master Degree of Arts of Texas University. Austin, Texas; 1947, 8, p. 10-11.

13. Camp VE, Roobol MJ. Upwelling asthenosphere beneath western Arabia and its regional implications. J Geophys Res Solid Earth. 1992;97(B11):15255-71.

14. Wernicke B. Uniform-sense normal simple shear of the continental lithosphere. Can J Earth Sci. 1985;22(1):108-25.

15. Voggenreiter W, Hotzl H, Jado A. Red Sea related history of extension and magmatism in the Jizan area (Southwest Saudi Arabia): indication for simple-shear during early Red Sea rifting. Geol Rundsch. 1988;77:257-74.

16. Mcguire AV, Bohannon RG. Timing of mantle upwelling: evidence for a passive origin for the Red Sea rift. J Geophys Res Solid Earth. 1989:94(B2):1677-82

17. Bellahsen N, Faccenna C, Funiciello F, Daniel JM, Jolivet L. Why did Arabia separate from Africa? Insights from 3-D laboratory experiments. Earth Planet Sci Lett. 2003;216(3):365-81.

18. Cochran JR. A model for development of Red Sea. AAPG Bull. 1983;67:41-69.

19. Pichon $X L$, Francheteau J. A plate-tectonic analysis of the Red Sea-Gulf of Aden Area. Tectonophysics. 1978;46(3-4):369,391-388,406.

20. Johnson PR. Tectonic map of Saudi Arabia and adjacent areas. Saudi Geological Survey, Deputy Ministry for Mineral Resources Technical Report USGS-TR-98-3, 1998, (IR 948)

21. Jackson J, Mckenzie D. Active tectonics of the Alpine-Himalayan Belt between western Turkey and Pakistan. Geophys J Int. 1984;77(1):185-264.

22. Dewey JF, Hempton MR, Kidd WSF, Saroglu F, Sengor AMC. Shortening of continental lithosphere: the neotectonics of Eastern Anatolia-a young collision zone. Collis Tecton. 1986:19(1):1-36.

23. Jackson J, Mckenzie D. Rates of active deformation in the Aegean Sea and surrounding regions. Basin Res. 1988;1(3):121-8.

24. Ring U, Layer PW. High-pressure metamorphism in the Aegean, eastern Mediterranean: underplating and exhumation from the Late Cretaceous until the Miocene to Recent above the retreating Hellenic subduction zone. Tectonics. 2003;22(3):1022. https://doi.org/10.1029/2001TC001350.

25. Levin HL. The earth through time. 7th ed. The United States of America: von Hoffmann Press; 2003.

26. Mouty M, Delaloye M, Fontignie D, Piskin $\mathrm{O}$, Wagner JJ. The volcanic activity in Syria and Lebanon between Jurassic and actual. Schweiz Miner Petr Mitt. 1992;72:91-105

27. Chorowicz J, Dhont D, Ammar O, Rukieh M, Bilal A. Tectonics of the Pliocene Homs basalts (Syria) and implications for the Dead Sea Fault Zone activity. J Geol Soc. 2005;162(2):259-71.
28. Abdel-Rahman AFM, Nassar PE Cenozoic volcanism in the Middle East: petrogenesis of alkali basalts from northern Lebanon. Geol Mag. 2004;141(5):545-63.

29. Segev A. Magmatic rocks. Geological framework of the Levant, vol. 2, Part 4. Historical Production-Hall, Jerusalem, p. 553-576.

30. Trifonov VG, Dodonov AE, Sharkov EV, Golovin DI, Chernyshev IV, Lebedev VA, Ivanova TP, Bachmanov DM, Rukieh M, Ammar O, Minini H, Al Kafr AM, Ali O. New data on the Late Cenozoic basaltic volcanism in Syria, applied to its origin. J Volcanol Geother Res. 2011;199(3-4):177-92.

31. Chang SJ, Lee SVD. Mantle plumes and associated flow beneath Arabia and East Africa. Earth Planet Sci Lett. 2011;302(3-4):448-54.

32. Fu H, Fu BH, Ninomiya Y, Shi PL. New Insights of Geomorphologic and Lithologic Features on Wudalianchi Volcanoes in the Northeastern China from the ASTER Multispectral Data. Rem Sens. 2019;11(22):2663. https:// doi.org/10.3390/rs11222663.

33. Iwamori $\mathrm{H}$. Zonal structure of Cenozoic basalts related to mantle upwelling in southwest Japan. J Geophys Res Solid Earth. 1991:96(B4):6157-70

34. Zhao DP, Hasegawa A, Kanamori H. Deep structure of Japan subduction zone as derived from local, regional, and teleseismic events. J Geophys Res Solid Earth. 1994;99:2313-22329.

35. Zhao DP, Xu Y, Wien D. Depth extent of the lau back-arc spreading center and its relation to subduction processes. Science. 1997;278:254-7.

36. Zhao DP, Mishra OP, Sanda R. Influence of fluids and magma on earthquakes: seismological evidence. Phys Earth Planet Inter. 2002;132:249-67.

37. Wei W, Hammond JOS, Zhao DP, Xu J, Liu Q, Gu Y. Seismic evidence for a mantle transition zone origin of the Wudalianchi and Halaha volcanoes in northeast China. Geochem Geophys Geosyst. 2019;20:398-416.

38. Kereszturi G, Nemeth K, Moufti MR, Cappello A, Murcia H, Ganci G, Negro CD, Procter J, Zahran HMA. Emplacement conditions of the $1256 \mathrm{AD}$ AlMadinah lava flow field in Harrat Rahat, Kingdom of Saudi Arabia-Insights from surface morphology and lava flow simulations. J Volcanol Geoth Res. 2016:309:14-30.

39. Tao KY. Cheju island volcano in South Korea and its correlation with Wudalianchi and Leiqiong volcanoes in China. Resour Surv Environ. 2015:36(2):152-6.

\section{Publisher's Note}

Springer Nature remains neutral with regard to jurisdictional claims in published maps and institutional affiliations.

\section{Submit your manuscript to a SpringerOpen ${ }^{\circ}$ journal and benefit from:}

- Convenient online submission

- Rigorous peer review

- Open access: articles freely available online

- High visibility within the field

Retaining the copyright to your article

Submit your next manuscript at springeropen.com 